DOI 10.35220/2078-8916-2020-37-3-50-59

УДК 616.716.4-089.843-77:612.76]-059.1

Д.М. Черногорський, Ю.В. Чепурний, к. мед.н., А.В. Копчак, о. мед. н.

Національний медичний університет ім. О.О. Богомольця, Київ

\section{ВИВЧЕННЯ БІОМЕХАНІЧНИХ \\ ВЛАСТИВОСТЕЙ ЕНДОПРОТЕЗІВ \\ ТА ПАЦІЕНТОСПЕЦИФІЧНИХ \\ ІМПЛАНТАТІВ ДЛЯ ЗАМІЩЕННЯ \\ СУБТОТАЛЬНИХ ДЕФЕКТІВ НИЖНЬОЇ \\ ЩЕЛЕПИ МЕТОДОМ СКІНЧЕННИХ ЕЛЕМЕНТІВ}

Bступ. Замішення великих дефектів нижньої щелепи залишається актуальною проблемою щцелепно-лицевоі хірургї, щзо має важливе медико-сочіальне та економічне значення.

Мета дослідження. Вивчити напруженодеформований стан різних типів пацієнтоспецифічних титанових імплантатів при заміщенні субтотальних дефектів нижньої щелепи за допомогою методу скінченим елементів, оцінити їх жорсткість та міцність в умовах жувального навантаження.

Матеріали і методи. Проведене дослідження передбачало створення $i$ розрахунок 3 імітаційних комп'ютерних моделей нижньої щелепи із відтвореним субтотальним дефектом, який заміщували пацієнто-специфічними імплантатами/ендопротезами трьох різних типів, моделювання яких проводили відповідно до протоколів і рекомендачій.

Висновки. Таким чином, всі досліджені конструкції пацієнто-специифічних імплантатів забезпечують необхідну жорсткість і міцність в умовах пережовування м'якої їжі.

Для підтвердження отриманих даних водночас необхідні подальші порівняльно-механічні та клінічні дослідження.

Ключові слова: ендопротези, пацієнтоспециффічні імплантати, дефекти нижньої щелепи.

\section{Д.М. Черногорский, Ю.В. Чепурний,} A.В. Копчак

Национальный медицинский университет имени А. А. Богомольца, Киев

\section{ИЗУЧЕНИЕ БИОМЕХАНИЧЕСКИХ СВОЙСТВ ЭНДОПРОТЕЗОВ И ПАЦИЕНТО-СПЕЦИФИЧЕСКИХ ИМПЛАНТАТОВ ДЛЯ ЗАМЕЩЕНИЯ СУБТОТАЛЬНЫХ ДЕФЕКТОВ НИЖНЕЙ ЧЕЛЮСТИ МЕТОДОМ КОНЕЧНЫХ ЭЛЕМЕНТОВ}

Вступление. Замещуение больиих дефектов нижней челюсти остается актуальной проблемой челюстнолицевой хирургии, что имеет важное медикосочичальное и экономическое значение.
Цель исследования. Изучить напряженнодеформированное состояние различных типов пациенто-специфических титановых имплантатов при замещении субтотальных дефектов нижней челюсти с помощью метода конечным элементом, оченить их жесткость и прочность в условиях жевательной нагрузки.

Материаль и методы. Проведенное исследование предусматривало создание и расчет 3 имитационных компьютерных моделей нижней челюсти с воспроизведенным субтотальным дефектом, который замещзали пациенто-специфическими имплантатами / эндопротезами трех различных типов, моделирование которых проводили в соответствии с протоколами и рекомендациями.

Выводы. Таким образом, все исследованные конструкиии пациенто-специифических имплантатов обеспечивают необходимую жесткость и прочность 6 условиях пережевывания мягкой пищии.

Для подтверждения полученных данных в то же время необходимы дальнейшие сравнительномеханические и клинические исследования.

Ключевые слова: эндопротезы, пациентоспецифические имплантаты, дефекты нижней челюсти

\section{D.M. Chernogors'kyj, Ju.V. Chepurnyj, A.V. Kopchak}

Bogomolets National Medical University, Kyiv

STUDY OF BIOMECHANICAL PROPERTIES OF ENDOPROSTHESES AND PATIENT-SPECIFIC IMPLANTS FOR REPLACEMENT OF SUBTOTAL DEFECTS OF THE LOWER JAW BY THE FINITE ELEMENT METHOD

\section{ABSTRACT}

Introduction. Replacement of large defects of the lower jaw remains an urgent problem of maxillofacial surgery, which is of great medical,social and economic importance.

Purpose of research. To study the stress-strain state of various types of patient-specific titanium implants when replacing Subtotal defects of the lower jaw using the finite element method, to assess their rigidity and strength under chewing load.

Materials and methods. The study included the creation and calculation of 3 simulation computer models of the lower jaw with a reproduced Subtotal defect, which was replaced with patient-specific implants / endoprostheses of three different types, which were modeled in accordance with the protocols and recommendations.

Conclusions. Thus, all the studied designs of patientspecific implants provide the necessary rigidity and strength in the conditions of chewing soft food.

At the same time, further comparative mechanical and clinical studies are needed to confirm the data obtained. Key words: endoprostheses, patient-specific implants, lower jaw defects.

(C) Черногорський Д.М., Чепурний Ю.В., Копчак А.В., 2020. 
Зв'язок публікації 3 плановими науководослідними роботами. Робота $є$ фрагментом НДР «Наукове обгрунтування ранньої діагностики генералізованих захворювань пародонта хронічного та загостреного перебігу», № державної реєстрації $0118 \mathrm{U} 100471$.

Bcmyn. Заміщення великих дефектів нижньої щелепи (ДНЩ) залишається актуальною проблемою щелепно-лицевої хірургії, що має важливе медико-соціальне та економічне значення. Нижня щелепа людини має унікальну, геометрично-складну будову і функцію, пов'язану iз пережовуванням їжі, ковтанням та мовою. Дефекти значної протяжності з порушенням іiі неперервності супроводжуються спотворенням обличчя, погіршенням стану соматичного здоров'я в наслідок неможливості повноцінного харчування, виникненням глибоких психоемоційних розладів, різким зниженням якості життя, частковою чи повною втратою працездатності та соціальною дезадаптацією пацієнтів.

ДНЩ утворюються після проведення хірургічних втручань 3 приводу доброякісних та злоякісних новоутворень, остеомієлітів та остеонекрозів, що виникають внаслідок опромінення та прийому певних медикаментозних препаратів чи наркотичних речовин (MRONJ), травматичних ушкоджень та вроджених вад розвитку. Вони характеризуються значною варіативністю розмірів i форм, зміною топографо-анатомічних співвідношень обличчя, та вираженим функціональним дефіцитом, пов'язаним із порушенням неперервності щелепи, втратою одного чи двох скронево-нижньощелепних суглобів (СНЩС) та розбалансуванням роботи різних груп жувальних м'язів [1].

Основним завданням комплексного лікування пацієнтів цієї категорії є відтворення контуру нижньої щелепи, іiі позиціонування в просторі із відновленням нормальної оклюзії та правильних анатомічних співвідношень у СНЩС, що загалом має забезпечити пацієнту адекватну жувальну функцію та задовільний естетичний результат [2]. Для заміщення дефектів нижньої щелепи були запропоновані численні способи хірургічних втручань, що передбачали застосування кісткових трансплантатів, тканинно-інженерних комплексів, стандартних та індивідуалізованих імплантатів/ендопротезів, реконструктивних пластин та дистракційно-компресійних апаратів [3].

Золотим стандартом безпосередньої або відстроченої реконструкції нижньої щелепи є застосування васкуляризованих та неваскуляризованих кісткових ауто трансплантатів з гребеня клубової кістки, малогомілкової кістки, лопатки тощо. Воно дозволяє ефективно відновити неперервність нижньої щелепи та створити умови для майбутньої протетичної реабілітації, в тому числі конструкціями із опорою на дентальні імплантати [4-6]. Зазвичай, для надання необхідної форми кісткові трансплантати потребують сегментації із наступною фіксацією фрагментів один до одного та до залишків нижньої щелепи за допомогою накісних фіксаторів (пластин, сіток, конструкцій у формі жолоба).

Альтернативою традиційним методам кісткової пластики на сьогоднішній день є застосування пацієнтоспецифічних імплантатів та ендопротезів, виготовлених 3 титану на основі $\mathrm{CAD} / \mathrm{CAM}$ технології методами селективного лазерного спікання (DMLS) або фрезерування на станках з ЧПУ (CNC-milled). Вони дозволяють зменшити тривалість та складність хірургічного втручання, покращити його естетичні результати і зменшити об'єм забору кісткової тканини для трансплантації

На сьогоднішній день можна стверджувати, що технології CAD і CAM, взаємно доповнюючи одне одного, відкрили новий напрямок в реконструктивній хірургії обличчя - цифрова хірургія (computer aided surgery), в основу якої покладені алгоритми, що інтегрують сучасні можливості цифрової діагностики, комп'ютерної обробки даних, візуалізації, віртуальної симуляції та комп'ютерного моделювання, інтраопераційної навігації, виробництва імплантатів та пристроїв медичного призначення [7]. Сучасні методи комп'ютерного моделювання та порошкової металургії, зокрема селективне лазерне спікання титану на основі САМ технології дозволяють виготовляти складні тривимірні металеві конструкції, в тому числі PSI, забезпечуючи оптимальні параметри (геометрію, розмір, вагу) необхідні для даного пацієнту в наявних клінічних умовах $[8,9]$.

Велику кількість різноманітних інженерних рішень та конструкцій пацієнто-специфічних імплантатів (PSI), що використовують в реконструктивній щелепно-лицевій хірургії можна розділити на 2 основні групи - індивідуалізовані фіксатори (пластини, сітки, жолобки тощо), які використовують для закріплення кісткових трансплантатів та фрагментів щелепи в правильному положенні та ендопротези щелепи - конструкції 3 титану або полімерних матеріалів, які частково чи повністю заміщують втрачені кісткові структури [10-12]. Клінічна ефективність застосування пацієнто-специфічних імплантатів та ендопротезів в реконструкції нижньої щелепи була продемонстрована в ряді досліджень, опублікованих в останні роки [13-19]. Автори застосовували різні типи PSI, виготовлених методом селективного лазерного спікання від простих фіксаторів в формі жолоба до складних ендопротезів із відтво- 
ренням елементів СНЩС, точок прикріплення м'язів, наявністю елементів для фіксації кісткових блоків та зубних протезів. Основними перевагами застосування цього підходу, згідно отриманих даних були додаткове підвищення точності хірургічних втручань, що позначалося на досягнутих естетичних результатах, більші можливості в заміщенні великих дефектів зі складною геометрією, скорочення операційного часу та кількості оперативних втручань, необхідних для повноцінної реабілітації пацієнтів, точніше прилягання імплантатів, зменшення об'єму аутологічних кісткових трансплантатів [20].

Відомо, що титанові конструкції, які використовують для заміщення дефектів щелепи (самостійно, або у поєднанні із кістковими ауто трансплантатами) суттєво відрізняються від неї за своєю структурою, фізико-хімічними та механічними властивостями.

Одиничні роботи, присвячені даному питанню свідчать, що надійність конструкції при тривалому багаторічному функціональному навантаженні значною мірою залежить від іiі дизайну і особливостей взаємодії із ушкодженою нижньою щелепою, форма, архітектоніка та фізикомеханічні і біологічні властивості якої можуть змінюватись під впливом патологічних процесів та травмувальних чинників.

Автори вказують, що за певних умов концентрація напружень в середині ендопротезу може призводити до його руйнування від втоми у віддаленому післяопераційному періоді. В зв'язку із цим впровадження нових конструкцій пацієнтоспецифічних імплантатів та удосконалення їх дизайну має відповідати не лише анатомічним та виробничим вимогам але й забезпечувати необхідні біомеханічні властивості: жорсткість, міцність і надійність. Перевірка цих параметрів методами імітаційного комп'ютерного моделювання на доклінічному етапі дозволить уникнути низки ускладнень i незадовільних результатів, пов'язаних iз використанням механічнонедосконалих конструкцій в хірургічній практиці [21]. На думку ряду авторів такі дослідження $\epsilon$ важливим елементом оптимізації методів та засобів реконструктивної хірургії нижньої щелепи, a також планування i реалізації хірургічних втручань на основі біомеханічно-обгрунтованих критеріїв.

Мета дослідження. Вивчити напруженодеформований стан різних типів пацієнтоспецифічних титанових імплантатів при заміщенні субтотальних дефектів нижньої щелепи за допомогою методу скінченим елементів, оцінити їх жорсткість та міцність в умовах жувального навантаження.
Матеріали $\boldsymbol{i}$ методи. Проведене дослідження передбачало створення і розрахунок 3 імітаційних комп'ютерних моделей нижньої щелепи із відтвореним субтотальним дефектом, який заміщували пацієнто-специфічними імплантатами/ендопротезами трьох різних типів, моделювання яких проводили відповідно до протоколів і рекомендацій.

Концептуальний дизайн пацієнтоспецифічних імплантатів. В усіх моделях було відтворено субтотальний дефект правої половини нижньої щелепи (від правого ікла до голівки нижньої щелепи включно). Перший тип пацієнто-специфічного-імплантату представляв собою повно-анатомічний суцільний ендопротез, який не передбачав додаткового застосування будьяких кісткових ауто-трансплантатів. В основу дизайну конструкції було покладено технічні piшення, запропоновані компанією Xilloc Medical BV для повно-анатомічного титанового ендопротезу нижньої щелепи із модифікаціями, що визначались розміром і локалізацією змодельованого дефекту. Так, ендопротез представляв собою жорстку титанову балку, форма якої відповідала контуру нижнього і заднього краю щелепи (за відзеркаленою здоровою стороною) із отворами овальної чи трикутної форми, що застосовували для фіксації м'язів та полегшення конструкції (рис. 1). На ділянці кута площа поперечного перетину титанової конструкції була збільшена. Суглобову з титану голівку відтворювали відповідало до форми контра латеральної неушкодженої голівки нижньої щелепи. В передньому відділі титанова балка переходила в жолоб, що щільно охоплював нижній край щелепи на ділянці підборіддя в межах 31 - 43 зубів і містив отвори для 7 фіксуючих бікортикальних шурупів.

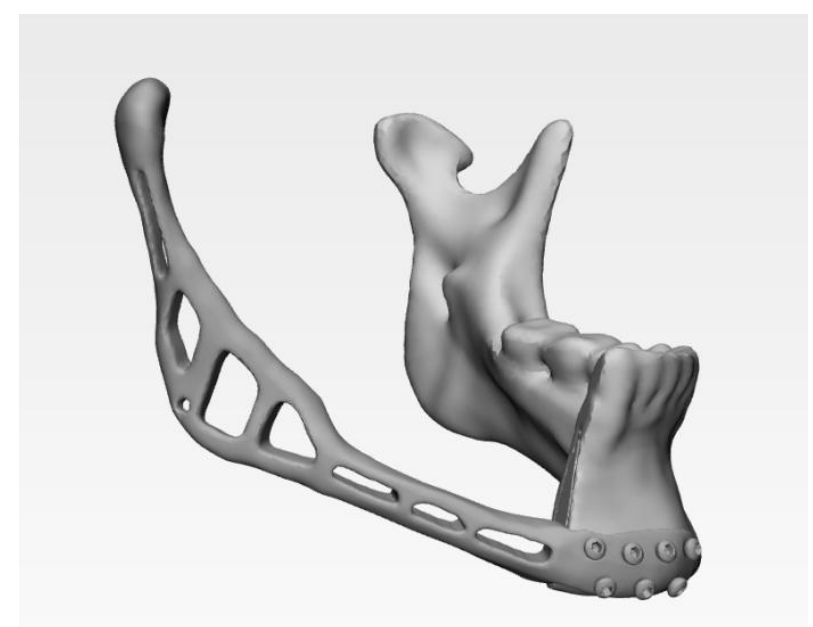

Рис. 1 Пацієнто-специфічний імплантат: повноанатомічний суцільний ендопротез нижньої щелепи. 
Другий тип пацієнто-специфічного імплантату представляв собою оригінальну комбіновану конструкцію, що поєднувала елементи ендопротезу та пацієнто-специфічного фіксатора (рис. 2). Він передбачав відновлення гілки нижньої щелепи - анатомічним ендопротезом, а тіла - кістковим трансплантатом. В якості кісткового аутотрансплантату було змодельовано фрагмент малогомілкової кістки, що одним своїм кінцем контактував 3 нижньою щелепою, а другим впирався в основу титанового ендопротезу. Для позиціювання і фіксації ауто трансплантату застосовували елемент конструкції в формі жолоба, що охоплював аутотрансплантат і підборіддя знизу і вестибулярно, відтворюючи контур нижньої щелепи, та містив отвори для фіксуючих шурупів (7 на ділянці підборіддя і 5 на ділянці аутотрансплантату).

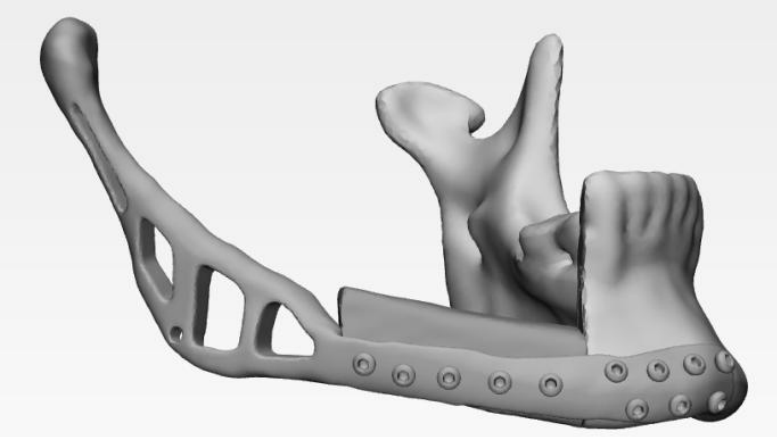

Рис. 2. Пацієнто-специфічний імплантат: комбінована конструкція, що поєднувала елементи ендопротезу та пацієнто-специфічного фіксатора.

Третій тип конструкції представляв собою класичний пацієнто-специфічний фіксатор в формі жолоба (рис.3). Він забезпечував з'єднання фрагменту нижньої щелепи і 3-х кісткових аутотрансплантатів необхідних для відтворення втрачених ділянок тіла і гілки нижньої щелепи, за виключенням голівки нижньої щелепи, яку відновлювали титановим елементом конструкції. В моделі розглядали ситуацію, де в якості кісткового аутотрансплантату використовували остеотомований і розділений на 3 частини фрагмент малогомілкової кістки, співставлений в положенні, що найбільшою мірою відповідало формі втраченої частини нижньої щелепи. При цьому пацієнто-специфічний імплантат виконував роль реконструктивного шаблону, забезпечував правильне позиціонування фрагментів відносно щелепи та один одного, їх фіксацію в правильному положенні за допомогою 19 фіксуючих шурупів, та відновлення анатомічно правильного контуру нижнього і заднього краю щелепи.

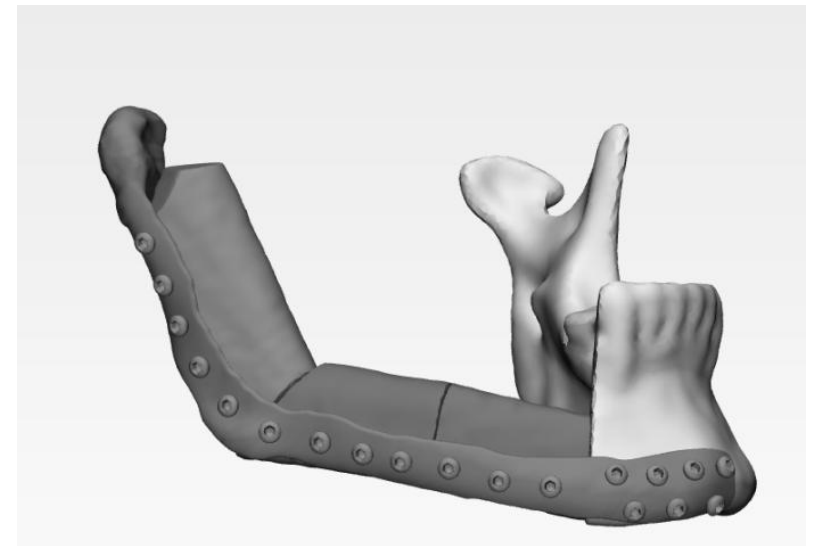

Рис. 3. Пацієнто-специфічний імплантат: пацієнтоспецифічний фіксатор в формі жолоба.

Таким чином запропоновані конструкції забезпечували різне співвідношення штучних титанових конструкцій із кістковими трансплантатами та збереженим фрагментом нижньої щелепи, створюючи різні умови для розподілу жувальних навантажень в системі імплантат-кістка. При цьому дизайн всіх трьох типів PSI за допомогою геометричного підходу та детально описаних протоколів дозволяв відновити симетрію нижньої щелепи і анатомічну відповідність титанової голівки до збережених елементів СНЩС

Побудова 3D-моделей. Тривимірна віртуальна модель нижньої щелепи була створена в програмному середовищі Mimics 12.1 (Materialize, Бельгія) на основі даних комп'ютерної томографії (КТ) лицевого черепа пацієнта із інтактною нижньою щелепною, що мала нормальну анатомічну форму та розміри.

КТ проводили за допомогою мультиспірального сканера Toshiba Aquilon 163 товщиною зрізу 0,5 мм. Дані КT в вигляді DICOM файлів були імпортовані в програмне забезпечення Mimics 12.1, де спершу проводили сегментацію зображення зі створенням «маски» в діапазоні, що відповідав рентгенологічній щільності кісткової тканини. Створену поверхневу полігональну модель у вигляді файлу формату stl експортували в програмний комплекс Geomagic Freeform Plus, де проводили перевірку на помилки геометрії із наступною їх корекцією. Моделі стандартних фіксуючих шурупів довжиною 12 мм та діаметром 2.1 мм було створено за допомогою програмного комплексу CAD Autodesk Inventor (Autodesk, Inc., San Rafael, Каліфорнія) та імпортовано в програмне середовище Mimics 12.1. Всі створені поверхневі моделі за допомогою булевих операцій були об'єднані в багатокомпонентні збірки “щелепа-кісткові аутотрансплантати-PSIфіксуючі шурупи” та імпортовані до програмного забезпечення Ansys 5.7 для подальшого роз- 
биття об'ємної скінченно-елементної сітки.

Створення скінченно-елементної сітки та властивості матеріалів. Препроцесінг моделей проводили в програмному забезпеченні Ansys 5.7 (Swanson Ansys Inc., Х'юстон, штат Пенсільванія, США). Для кожного 3 елементів моделі були створені об'єми та розбита скінченно-елементна сітка 3 подальшим призначенням відповідих властивостей матеріалу. На ділянках зі складною геометрією та в зонах концентрації напружень вдавались до згущення сітки. Основні механічні властивості кістки та титанових конструкцій було завдано відповідно до наявних літературних даних. Для спрощення чисельних розрахунків кісткову тканину розглядали як тверду, гомогенну (в межах одного типу матеріалу), лінійно еластичну та ізотропну, як у більшості біомеханічних досліджень, виконаних за допомогою МСЕ. Модуль Юнга для кортикального шару нижньої щелепи становив 13 ГПа відповідно до експериментальних даних, опублікованих в роботах Маланчук В.О., Крищук М.Г., Копчак А.В, 2013. Для губчастої кістки значення модуля Юнга становило 0,8 ГПа, а для кісткового трансплантату із малогомілкової кістки - 7 ГПа. Коефіцієнт Пуассона $v$ приймали рівним 0,3 для всіх типів кістки. Шурупам та пацієнто-специфічним імплантатам було надано властивостей титанового сплаву Ti-6Al-4V, Grade $5(\mathrm{E}=110 \mathrm{GPa}, v=$ $0,34)$. У створених моделях ми нехтували структурними та механічними особливостями дентоальвеолярного комплексу та періодонтальної зв'язки як несуттєвими.

Навантаження та граничні умови скінченно-елементних моделей. У даному дослідженні було відтворено умови жувального навантаження в стані передньої оклюзії при ізотонічному скороченні м'язів, що піднімають нижню щелепу. При встановленні імплантатів запропонованих конструкцій в реальних умовах повністю втрачається точка прикріплення скроневого і латерального криловидного м'язів, а жувальний і медіальний крило видний м'язи, що фіксуються до ретенційних елементів імплантату повністю не відновлюють свою скоротливу здатність. Зважаючи на суттєве зниження функціональної активності жувальних м'язів у пацієнтів з субтотальними дефектами нижньої щелепи, візначене в роботах [22] силу прикусу завдавали на рівні 100 Н, що відповідає пережовуванню м'якої їжі.

Силу прикусу розподіляли вздовж ріжучого краю різців та ікол. За даних умов навантаження, активними вважали 5 пар м'язів, включаючи медіальну криловидну, поверхневу та глибоку порцію власне жувального м'язу, передню та задню порцію скроневого м'язу (на здоровій стороні). Модель була закріплена на ділянці суглобової поверхні голівки нижньої щелепи та титанового ендопротезу з нульовим ступенем свободи для лінійних переміщень та ротаційних рухів.

Контакти між фіксуючими шурупами та пацієнто-специфічним імплантатом, між шурупами та кісткою, а також між кістковими ауто трансплантатами і збереженим фрагментом щелепи розглядали, як bonded. В усіх випадках числове piшення відповідало лінійно-еластичній моделі напружено деформованого стану в умовах статичного навантаження. Після розрахунку кожної моделі визначали загальну деформацію системи (як максимальне переміщення вузлів при деформуванні), максимальні значення головних та еквівалентних напружень, а також закономірності розподілу напружень та деформацій представлені у формі кольорових градієнтів або векторної графіки для кортикального, губчастого шару кістки (в тому числі кісткових ауто трансплантатів) та елементів титанової конструкції. Міцність i надійність системи «імплантат-кістка» оцінювали за максимальною величиною еквівалентних напружень в елементах фіксації та оточуючій кістковій тканині, співставляючи їх із граничнодопустимими значеннями для різних типів матеріалу відомих 3 літератури.

Результати. Об'єм титанових конструкцій включно із фіксуючими шурупами виявився найбільшим для PSI першого типу (суцільний ендопротез тіла і гілки нижньої щелепи) і становив $6628 \mathrm{mм}^{3}$. Для комбінованого ендопротезу (тип II) і PSI в формі жолоба цей параметр склав відповідно 5191 мм $^{3}$ та 2975 мм³ $^{3}$ В умовах жувального навантаження система імплантат-кістка в усіх випадках перебувала в умовах складного напружено-деформованого стану, що містив деформації розтягу-стиску, згину, крутіння і зсуву.

Жорсткість фіксації. Проведені розрахунки підтвердили, що за даних умов навантаження, змодельовані титанові конструкції забезпечували адекватну жорсткість і стабільність фіксації кісткових фрагментів. Найбільш адекватно вона характеризувалася значенням абсолютної деформаціï (total deformation) системи - тобто максимальним переміщенням (мм) вузлів моделі при функціональному навантаженні, що зворотнопропорційно жорсткості системи. Цей параметр виявлявся найбільшим для конструкції I типу і найменшим для конструкції III типу (відмінності в 2,14 рази). Відмінності в жорсткості між конструкціями II і III типу були значно меншими (на рівні $22 \%$ ). Загальний характер деформування при застосуванні різних типів титанових пацієнто-специфічних імплантатів був подібним і якісно не відрізнявся від деформування інтактної нижньої щелепи. Таким чином, суцільно титанова конструкція, що більш, як в 2 рази перевищу- 
вала конструкцію в формі жолоба за об’ємом, водночас забезпечувала меншу інтегральну жорсткість системи. Це було зумовлено особливостями дизайну та раціональним розташуванням титанових конструкцій поєднаних із кістковими блоками, що забезпечували ефект перерозподілу навантаження між титановим імплантатом і кісткою.

Напруження $і$ деформації в паціснтоспецифічних імплантатах. Відомо, що при циклічному жувальному навантаженні в конструкціях ендопротезів нижньої щелепи можуть виникати напруження, що перевищують граничну межу і можуть спричиняти руйнування конструкції, яке за даними літератури найбільш адекватно описується четвертою теорією міцності. Тому, в якості основного параметру, що застосовували для описання їх механічної поведінки використовували значення еквівалентних напружень за Мізесом.

В усіх типах конструкцій максимальні напруження були відзначені на ділянках контакту різьби шурупів із титановим імплантатом (рис. 4), де виникали концентратори напруження, зумовлені особливостями геометрії об'єкту, що не мають значного прикладного/клінічного значення. Їх величина на окремих ділянках невеликих сягала 250-300 МПа, але в навколишніх ділянках та в середині титанових елементів суттєво знижувалась. В конструкціях II і III типу більші значення напружень загалом спостерігали в шурупах встановлених на ділянці кісткового ауто трансплантату (рис.5, рис.6), де не вдавалось досягнути щільного контакту імплантату із кісткою в зв’язку із їх геометричною невідповідністю.

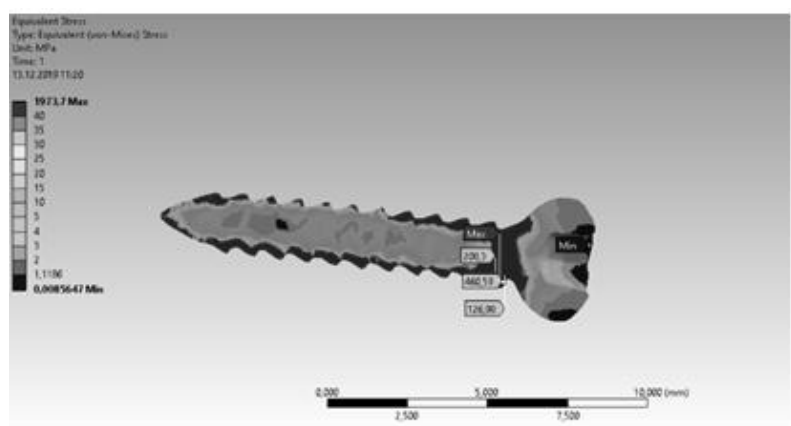

Рис. 4. Максимальні напруження на ділянках контакту різьби шурупа із титановим імплантатом.

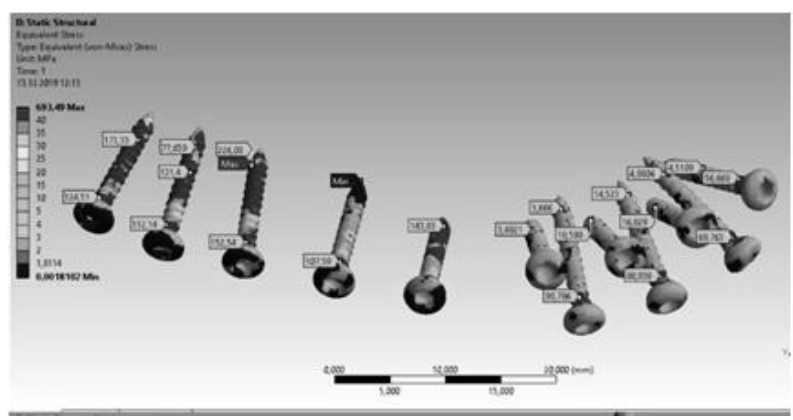

Рис. 5. Напруження в конструкції II типу в ділянці встановлених шурупів.

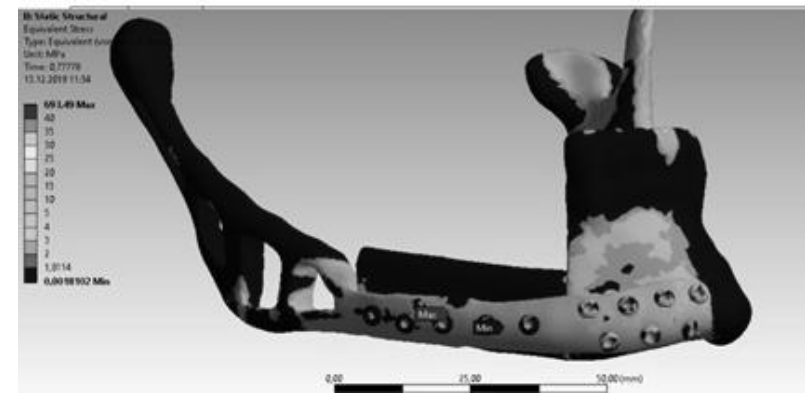

Рис. 6. Напруження в конструкції ІІ типу на ділянці кісткового ауто трансплантату.

Градієнти напруження були найбільшими в ендопротезі I типу (рис. 7), що працював переважно на згин. При цьому титанова балка, що формувала основу ендопротезу, демонструвала відносно рівномірний розподіл напружень, величина яких була незначною і не перевищувала 30 МПа. Основні ділянки концентрації напружень в ендопротезі відзначали в місці контакту балки із підборідним фіксуючим фрагментом та на ділянці контакту цього фрагменту із кісткою. Максимальна величина еквівалентних напружень тут перевищувала 150 МПа, а в окремих локаціях сягала 270-300 МПа.

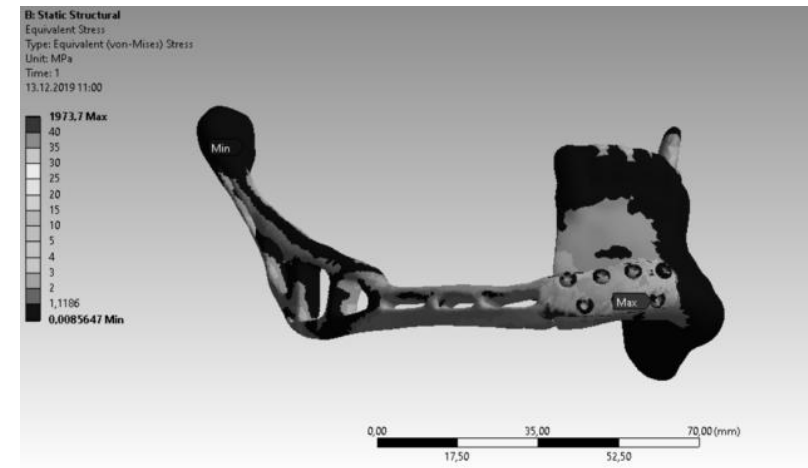

Рис. 7. Градієнти напруження в ендопротезі I типу.

В пацієнто-специфічному імплантаті II типу на ділянці титанової балки напруження були незначними до 15-20 МПа, крім місця безпосереднього контакту поверхні імплантату з кістковим блоком, де вони зростали до 30-45МПа. Це свідчило про передачу частини жувального навантаження через трансплантат на жорстку частину титанової конструкції, що певною мірою розвантажувало фіксуючу частину конструкції. Фіксуюча частина в свою чергу, виявлялась значно більш напруженою. Основні ділянки концентрації еквівалентних напружень визначали в зоні переходу жорсткої титанової балки в жолоб (до 60 МПа), в проекції зони контакту ауто трансплантату і кісткового фрагменту щелепи, що співпадала із зоною збільшеної кривизни нижньої щелепи, та в зоні фіксації конструкції до підборіддя, де напруження сягали 130-220 МПа. 
В імплантаті III типу (пацієнтоспецифічний фіксатор в формі жолоба) - напруження концентрувалися навколо отворів для фіксуючих шурупів та на внутрішній поверхні жолоба (рис. 8) для фіксації кісткових блоків в проекції тіла і кута щелепи. Величина еквівалентних напружень в зонах концентрації при цьому не перевищувала 150 МПа, і виявлялась найменшою серед всіх типів конструкцій.

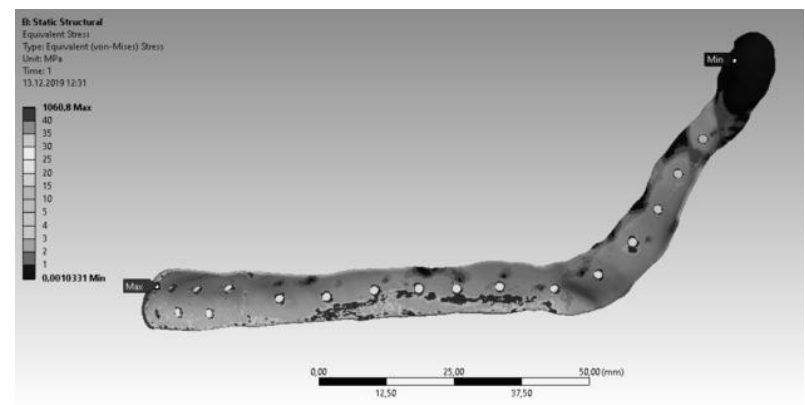

Рис. 8. Концентрація напруження навколо отворів для фіксуючих шурупів та на внутрішній поверхні жолоба в імплантаті III типу.

Напруження і деформації в кістковій тканині. В усіх моделях, в кістковій тканині гілки нижньої щелепи зберігався природній характер розподілу напружень і деформацій із зонами максимальної концентрації на ділянці зовнішньої косої лінії та нижньощелепного торусу (величина еквівалентних напружень в цих зонах сягала 10-12 МПа). Натомість на ділянці підборіддя під фіксуючим елементом пацієнто-специфічних імплантатів напруження зростали, із виникненням зон їх значної концентрації в кортикальному шарі кістки навколо фіксуючих шурупів.

В конструкції I типу (суцільний ендопротез нижньої щелепи) ділянки максимальної концентрації напружень відповідали першим 3-4 виткам різьби де їх величина сягала 40-60 МПа і більше, причому найбільш навантаженим виявлявся шуруп найближчий до дефекту: максимальна величина еквівалентних напружень за Мізесом в кортикальному шарі кістки навколо нього становила 86,5 МПа. В губчастму шарі кістки навколо шурупів значної концентрації напружень на виникало, вони не перевищували 7 МПа в жодному спостереженні.

В конструкції II типу характер розподілу напружень і деформацій був якісно подібним, водночас величина еквівалентних напружень в кортикальному шарі нижньої щелепи була значно меншою і не перевищувала 25 МПа, розбіжності в величині еквівалентних напружень між окремими шурупами при цьому були меншими, розподіл навантаження ставав більш рівномірним. В губчастому шарі щелепи величина еквівалентних напружень не перевищувала 5 МПа. Напруження в кістковій тканині ауто трансплантату були незначними. Ділянки концентрації відзначали навколо фіксуючих шурупів (максимальні значення на рівні 6-8 МПа), а також в зонах контактної взаємодії із пацієнтоспецифічним імплантатом (до $20 \mathrm{MПа)} \mathrm{та} 3$ фрагментом нижньої щелепи (до $10 \mathrm{MПа).} \mathrm{Це} \mathrm{забезпечувало} \mathrm{перерозподіл} \mathrm{жу-}$ вального навантаження між кістковою тканиною та фіксуючим елементом в формі жолоба, в ході якого частина жувального навантаження сприймалась і перерозподілялась за рахунок кісткового ауто трансплантату.

В конструкції III типу (пацієнтоспецифічний фіксатор в формі жолоба) локальні ділянки концентрації напружень відзначали в кортикальному шарі кістки навколо фіксуючих шурупів. Їх значення були більшими в кортикальному шарі нижньої щелепи і сягали 25-27 МПа. Відмінності між величиною напружень навколо шурупів, встановлених в нижню щелепу також були меншими ніж в моделі I типу. III тип конструкції забезпечував перерозподіл жувального навантаження, як за рахунок індивідуалізованого імплантату так і за рахунок безпосередньої передачі навантаження на ділянці контакту щелепи із кістковими аутотрансплантатами. Напруження в зоні контактної взаємодії «щелепатрансплантат» сягали 23 МПа, а на ділянках контакту окремих фрагментів трансплантату між собою були меншими - до 4-6 МПа. В губчастому шарі кістки навколо шурупів напруження були невеликими і не перевищували 5 МПа.

Обговорення отриманих результатів. Впровадження CAD/CAM технології в реконструктивній щелепно-лицевій хірургії суттєво збільшило прогнозованість хірургічних втручань, зменшило вплив суб'єктивних чинників на результат операції та ризик виникнення інтраопераційних ускладнень, створило нові можливості в діагностиці, плануванні та реалізації лікувальної стратегії у пацієнтів, спростило виконання окремих етапів операцій, призвело до вірогідного скорочення операційного часу, покращення естетичних та функціональних результатів за рахунок більш точного відновлення контуру анатомічних структур та природної форми щелепи [23].

Автори виділяють 2 основних типи пацієнтоспецифічних імплантатів та низку проміжних комбінованих рішень: 1) пацієнтоспецифічні фіксатори у формі сіток, рамок, жолобів, які використовують в поєднанні з кістковими трансплантатами. Ці конструкції формують контур нижньої щелепи, визначають позицію кісткових трансплантатів та забезпечують їх стабільне утримання у визначеному положенні. 2) Ендопротези, 3 металу та полімерних матеріалів, що самі замі- 
щують втрачені частини нижньої щелепи і фіксуються до іï залишків. Перевагою пацієнтоспецифічних ендопротезів є можливість застосування в складних клініко-анатомічних умовах та за наявності системних чи місцевих протипоказань до мікросудинної пересадки кістки.

В останні роки, однак, 3'явилась велика кількість досліджень, згідно яких, важливими детермінантами довготривалого функціонування PSI та клінічної ефективності реконструкцій нижньої щелепи є механічні параметри конструкції та системи імплантат - кістка. Перебіг таких біологічних процесів, як резорбція, ремоделювання та регенерація кісткової тканини на ділянці проведеного хірургічного втручання значною мірою визначається видом ії напружено деформованого стану.

MCE широко застосовують для вивчення механічної поведінки інженерних конструкцій та складних природних структур, включаючи біологічні тканини. Він може бути застосований для вибору оптимального клінічного і інженерного рішення на етапі передопераційного планування iз використанням імплантатів різного типу, форми і конфігурації. Він дозволяє вивчати параметри, що не можуть бути безпосередньо визначені in vivo (наприклад, напруження i внутрішні деформації кісток і титанових конструкцій) на до клінічному етапі, удосконалювати і корегувати дизайн імплантатів, фіксаторів та ендопротезів щелепи на основі вивчення їх напружнодеформованого стану 3 метою уникнути ускладнень та негативних клінічних наслідків.

Попередні дослідження показали, що точність та адекватність скінченно-елементних моделей збільшується зі збільшенням геометричної деталізації і густини скінченно-елеменної сітки $10,22,24,33$. У аналогічних дослідженнях для представлення складної геометрії та внутрішньої структури нижньої щелепи автори використовували моделі, кількість скінченних елементів в яких складала від 22 тис. до 1,5 млн. В даному дослідженні моделі, створені на основі КТ пацієнта із нормально-сформованою нижньою щелепою складалися з 250 тис. скінченних елементів, причому вірогідність отриманих розрахункових рішень перевірялась тестом конвергенції. Крім детального відтворення геометрії щелепи особливу увагу приділяли точному відтворенню умов жувального навантаження і моделюванню сили ізотонічного скорочення, м'язів, що піднімають нижню щелепу. Граничні умови і навантаження моделі проводили, базуючись на концепції $[24,25]$, яку широко застосовують в робота по вивченню біомеханіки нижньої щелепи методом скінченних елементів [26-29]. Такі параметри моделі забезпечили необхідне наближення ре- зультатів моделювання до реальних клінічних умов та забезпечували можливість співставлення отриманих даних із результатами раніше опублікованих робіт.

Отримані в ході модельних розрахунків дані свідчать, що при застосуванні суцільного анатомічного ендопротезу нижньої щелепи для заміщення іiі субтотального дефекту, система імплантат-кістка демонструє найнижчі показники жорсткості, незважаючи на значний об’єм і площу поперечного перетину титанової конструкції. Крім того існує можливість виникнення кумулятивних ефектів в зонах локальної концентрації напружень (так зване руйнування від втоми) при циклічному жувальному навантаженні із частотою 2-3 тис жувальних рухів на день.

Еквівалентні напруження за Мізесом, що найбільш ефективно описують умову міцності титанових конструкцій при статичному і квазістатичному навантажені виявлялися найменшими в імплантаті III типу (пацієно-специфічний фіксатор в формі жолоба). Вони не перевищували 150 МПа і були в 1.4 разів меншими ніж гранично допустима величина для титанового сплаву Grade 5 (Ti6Al4V), що дозволяло розглядати імовірність руйнування імплантату при функціональному навантаженні, як нехтовно малу. Ця ж конструкція демонструвала найбільшу жорсткість і найбільш рівномірний розподіл напружень в середині імплантату. Конструкція II типу (комбінація ендопротезу гілки та пацієнтоспецифічного фіксатору, на ділянці тіла і підборіддя, змодельована згідно розробленого нами оригінального дизайну) за своїми характеристиками наближалася до конструкції III типу. Її жорсткість була лишень на $22 \%$ менше. I хоча напруження в елементах титанової конструкції були більшими на 32 \%, пацієнто-специфічний імплантат мав необхідний запас міцності. Натомість напруження в кістковій тканині були майже на $10 \%$ меншими ніж при застосуванні конструкції III типу. Таким чином із біомеханічної точки зору конструкції II і III типу були подібними і суттєво відрізнялися від I типу PSI. Водночас 3 технічної, хірургічної та біологічної точки зору відмінності між конструкціями II і III типу мали значні відмінності. PSI другого типу передбачав застосування одного кісткового блоку без його додаткової фрагментації. Це позитивно позначалось на його гемодинаміці після накладання мікросудинного анастомозу та дозволяло точно адаптувати його до збереженого фрагменту нижньої щелепи. В конструкціях подібних до III типу в реальних умовах дуже складно забезпечити хороше кровопостачання кісткових блоків (особливо дистального) та добитися їх щільного прилягання один до одного навіть при за- 
стосуванні навігаційних хірургічних шаблонів на етапі забору та фрагментації трансплантату. Ці технічні і біологічні обмеження можуть звести нанівець існуючі біомеханічні переваги конструкцій III типу і свідчать про доцільність вибору інших хірургічних рішень в значному відсотку клінічних випадків.

Дане дослідження має низку обмежень зумовлених застосованим методологічним підходом і притаманні будь-якому аналізу на основі імітаційного комп'ютерного моделювання. Вони пов'язані із певними спрощеннями та припущеннями прийнятими в моделі.

Так матеріали в даному дослідженні розглядались як лінійно-ізотропні і гомогенні, подібно до роботи [27]. Відомо, що кісткова тканина належить до анізотропних, нелінійних матеріалів, що можуть змінювати свої властивості в часі $[28,29]$. Крім того нижня щелепи людини в межах кортикального та губчастого шару є неоднорідною, а ії властивості у пацієнтів із субтотальними дефектами нижньої щелепи можуть суттєво змінюватись під впливом патологічних процесів, що призвели/супроводжували виникнення дефекту [30]. Механічні властивості титанового сплаву також значною мірою залежать від способу його обробки.

Отримані данні дозволяють виявити основні закономірності біомеханічної поведінки систем імплантат-кістка при заміщенні субтотальних дефектів нижньої щелепи, створюють підгрунтя для оптимізації дизайну ендопротезів та індивідуалізованих фіксаторів, а також обгрунтованого прийняття рішень в різних клінічних ситуаціях.

Висновки. Таким чином, всі досліджені конструкції пацієнто-специфічних імплантатів забезпечують необхідну жорсткість і міцність в умовах пережовування м'якої їжі. При збільшенні жувальних навантажень в конструкції I типу (суцільний ендопротез щелепи) та кістковій тканині навколо фіксуючих шурупів можуть виникати напруження і деформації, що перевищують гранично-допустимі значення. Пацієнтоспецифічні імплантати, що передбачають додаткове застосування кісткових аутотрансплантатів для заміщення дефектів щелепи демонструють більшу жорсткість та більш рівномірний розподіл напружень і деформацій, порівняно із суцільними ендопротезами за рахунок пререрозподілу навантаження між кісткою та титановою конструкцією. Збільшення кількості кісткових блоків для заміщення більшого об'єму дефекту тіла і гілки щелепи покращує біомеханічні характеристики системи незначною мірою водночас створює значні технічні складності та має низку біологічних обмежень. Це визначає переваги запропонованих нами комбінованих конструкцій, що поєднують ендопротезування гілки із кістковопластичним заміщенням тіла нижньої щелепи в переважній більшості клінічних ситуацій. Для підтвердження отриманих даних водночас необхідні подальші порівняльно-механічні та клінічні дослідження.

\section{REFERENCES}

1. Kim JW, Kim DY, Ahn KM, Lee JH. Surgical implications of anatomical variation in anterolateral thigh flaps for the reconstruction of oral and maxillofacial soft tissue defects: focus on perforators and pedicles. J Korean Assoc Oral Maxillofac Surg. 2016 Oct;42(5):265-270. doi: 10.5125/jkaoms.2016.42.5.265. Epub 2016 Oct 25. PMID: 27847734; PMCID: PMC5104868.

2. Hallermann W, Olsen S, Bardyn T, Taghizadeh F, Banic A, Iizuka T. A new method for computer-aided operation planning for extensive mandibular reconstruction. Plast Reconstr Surg. 2006 Jun;117(7):2431-7. doi: 10.1097/01.prs.0000219076. 83890.e8. PMID: 16772952.

3. Lee JT, Hsu H, Wang CH, Cheng LF, Sun TB, Huang CC, Chien SH. Reconstruction of extensive composite oromandibular defects with simultaneous free anterolateral thigh fasciocutaneous and fibular osteocutaneous flaps. J Reconstr Microsurg. 2010 Apr;26(3):145-51. doi: 10.1055/s-00291242134. Epub 2009 Nov 9. PMID: 19902408.

4. Hidalgo DA. Titanium miniplate fixation in free flap mandible reconstruction. Ann Plast Surg. 1989 Dec;23(6):498507. doi: 10.1097/00000637-198912000-00005. PMID: 2624393.

5. Cordeiro PG, Disa JJ, Hidalgo DA, Hu QY. Reconstruction of the mandible with osseous free flaps: a 10-year experience with 150 consecutive patients. Plast Reconstr Surg. 1999 Oct;104(5):1314-20. doi: 10.1097/00006534-19991000000011. PMID: 10513911.

6. Schlieve T, Hull W, Miloro M, Kolokythas A. Is immediate reconstruction of the mandible with nonvascularized bone graft following resection of benign pathology a viable treatment option? J Oral Maxillofac Surg. 2015 Mar;73(3):5419. doi: 10.1016/j.joms.2014.10.019. Epub 2014 Oct 31. PMID: 25683044.

7. Ciocca L, Mazzoni S, Fantini M, Persiani F, Marchetti C, Scotti R. CAD/CAM guided secondary mandibular reconstruction of a discontinuity defect after ablative cancer surgery. J Craniomaxillofac Surg 2012;40(8): e511-5.

8. Figliuzzi M, Mangano F, Mangano C. A novel root analogue dental implant using $\mathrm{CT}$ scan and CAD/CAM: selective laser melting technology. Int J Oral Maxillofac Surg. 2012 Jul;41(7):858-62. doi: 10.1016/j.ijom.2012.01.014. Epub 2012 Feb 28. PMID: 22377004.

9. Williams JV, Revington PJ. Novel use of an aerospace selective laser sintering machine for rapid prototyping of an orbital blowout fracture. Int J Oral Maxillofac Surg. 2010 Feb;39(2):182-4. doi: 10.1016/j.ijom.2009.12.002. Epub 2010 Jan 12. PMID: 20064702.

10. Samman N, Luk WK, Chow TW, Cheung LK, Tideman H, Clark RK. Custom-made titanium mandibular reconstruction tray. Aust Dent J. 1999 Sep;44(3):195-9. doi: 10.1111/j.1834-7819. 1999.tb00221.x. PMID: 10592564.

11. Singare S, Dichen L, Bingheng L, Yanpu L, Zhenyu G, Yaxiong L. Design and fabrication of custom mandible titanium tray based on rapid prototyping. Med Eng Phys. 2004 Oct;26(8):671-6. doi: 10.1016/j.medengphy.2004.06.001. PMID: 15471695.

12. Peckitt NS. Stereoscopic lithography: customized titanium implants in orofacial reconstruction. A new surgical technique without flap cover. Br J Oral Maxillofac Surg. 1999 
Oct;37(5):353-69. doi: 10.1054/bjom.1999.0070. PMID: 10577749.

13. Goto M, Katsuki T, Noguchi N, Hino N. Surgical simulation for reconstruction of mandibular bone defects using photocurable plastic skull models: report of three cases. J Oral Maxillofac Surg. 1997 Jul;55(7):772-80. doi: 10.1016/s02782391(97)90597-8. PMID: 9216515.

14. Hirsch DL, Howell KL, Levine JP. A novel approach to palatomaxillary reconstruction: uses of radial forearm free tissue transfer combined with zygomaticus implants. J Oral Maxillofac Surg. 2009 Nov;67(11):2466-72. doi 10.1016/j.joms.2009.04.062. PMID: 19837319.

15. Leiggener $C$, Messo $E$, Thor A, Zeilhofer HF, Hirsch JM. A selective laser sintering guide for transferring a virtual plan to real time surgery in composite mandibular reconstruction with free fibula osseous flaps. Int J Oral Maxillofac Surg. 2009 Feb;38(2):187-92. doi: 10.1016/j.ijom.2008.11.026. PMID: 19179046.

16. Sharaf B, Levine JP, Hirsch DL, Bastidas JA, Schiff BA, Garfein ES. Importance of computer-aided design and manufacturing technology in the multidisciplinary approach to head and neck reconstruction. J Craniofac Surg. 2010 Jul;21(4):1277-80. doi: 10.1097/SCS.0b013e3181e1b5d8 PMID: 20613609.

17. Antony AK, Chen WF, Kolokythas A, Weimer KA, Cohen MN. Use of virtual surgery and stereolithography-guided osteotomy for mandibular reconstruction with the free fibula. Plast Reconstr Surg. 2011 Nov;128(5):1080-4. doi: 10.1097/PRS.0b013e31822b6723. PMID: 22030490.

18. Zheng GS, Su YX, Liao GQ, Chen ZF, Wang L, Jiao PF, Liu HC, Zhong YQ, Zhang TH, Liang YJ. Mandible reconstruction assisted by preoperative virtual surgical simulation. Oral Surg Oral Med Oral Pathol Oral Radiol. 2012 May;113(5):604-11. doi: 10.1016/j.tripleo.2011.05.016. Epub 2011 Aug 19. PMID: 22676986.

19. Mazzoni S, Marchetti C, Sgarzani R, Cipriani R, Scotti R, Ciocca L. Prosthetically guided maxillofacial surgery: evaluation of the accuracy of a surgical guide and custom-made bone plate in oncology patients after mandibular reconstruction. Plast Reconstr Surg. 2013 Jun;131(6):1376-85. doi: 10.1097/PRS.0b013e31828bd6b0. PMID: 23714798.

20. Peel S, Bhatia S, Eggbeer D, Morris DS, Hayhurst C. Evolution of design considerations in complex craniofacial reconstruction using patient-specific implants. Proc Inst Mech Eng H. 2017 Jun;231(6):509-524. doi: 10.1177/0954411916681346. Epub 2016 Dec 25. PMID: 28019190.

21. Malanchuk VO, Kopchak AV, Kryshhuk M G. Determination of functional load modes in patients with traumatic fracture of the lower jaw after osteosynthesis using modern computer modeling methods. Klinichna hirurgija. 2013;3:53-58

22. Maurer P, Pistner H, Schubert J. Computergestützte Kaukraftanalyse bei Patienten mit Unterkieferkontinuitätsresektionen [Computer assisted chewing power in patients with segmental resection of the mandible]. Mund Kiefer Gesichtschir. 2006 Jan;10(1):37-41. German. doi: 10.1007/s10006-005-0656-y. PMID: 16315074.

23. Tarsitano A, Battaglia S, Crimi S, Ciocca L, Scotti R, Marchetti C. Is a computer-assisted design and computerassisted manufacturing method for mandibular reconstruction economically viable? J Craniomaxillofac Surg. 2016 Jul;44(7):795-9. doi: 10.1016/j.jcms.2016.04.003. Epub 2016 Apr 13. PMID: 27193477.

24. Korioth TW, Hannam AG. Mandibular forces during simulated tooth clenching. J Orofac Pain. 1994 Spring;8(2):17889. PMID: 7920353.

25. Koolstra JH, van Eijden TM. The jaw open-close movements predicted by biomechanical modelling. J Biomech. 1997 Sep;30(9):943-50. doi: 10.1016/s0021-9290(97)00058-4. PMID: 9302617.

26. Koolstra JH, van Eijden TM. Combined finiteelement and rigid-body analysis of human jaw joint dynamics. J Biomech. 2005 Dec;38(12):2431-9. doi: 10.1016/j.jbiomech.2004.10.014. Epub 2004 Dec 30. PMID: 16214491 .

27. Ichim I, Kieser JA, Swain MV. Functional significance of strain distribution in the human mandible under masticatory load: numerical predictions. Arch Oral Biol. 2007 May;52(5):465-73. doi: 10.1016/j.archoralbio.2006.10.020. Epub 2006 Nov 29. PMID: 17137552.

28. Ashman RB, Cowin SC, Van Buskirk WC, Rice JC. A continuous wave technique for the measurement of the elastic properties of cortical bone. J Biomech. 1984;17(5):349-61. doi: 10.1016/0021-9290(84)90029-0. PMID: 6736070.

29. Dechow PC, Nail GA, Schwartz-Dabney CL, Ashman RB. Elastic properties of human supraorbital and mandibular bone. Am J Phys Anthropol. 1993 Mar;90(3):291-306. doi 10.1002/ajpa.1330900304. PMID: 8460653.

30. Daegling DJ, Hylander WL. Biomechanics of torsion in the human mandible. Am J Phys Anthropol. 1998 Jan;105(1):73-87. doi: 10.1002/(SICI)10968644(199801)105:1<73: AID-AJPA7>3.0.CO;2-E. PMID: 9537929.

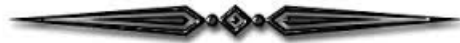

